\title{
Changes in polychaete standing stock and diversity on the northern side of Senghor Seamount (NE Atlantic)
}

\author{
A. J. Chivers, B. E. Narayanaswamy, P. A. Lamont, A. Dale, and R. Turnewitsch \\ The Scottish Association for Marine Science (SAMS), Scottish Marine Institute, Oban Argyll, PA37 1QA, Scotland, UK
}

Correspondence to: A. J. Chivers (adam.chivers@sams.ac.uk)

Received: 13 November 2012 - Published in Biogeosciences Discuss.: 18 December 2012

Revised: 24 April 2013 - Accepted: 30 April 2013 - Published: 3 June 2013

\begin{abstract}
Interest in seamount research has gathered momentum over the past five years in an effort to understand the physical, geochemical and biological characteristics as well as the interconnectedness of seamount ecosystems. The majority of biological seamount research has concentrated upon the rich and diverse suspension feeding organisms that dominate the megafauna, such as gorgonians and antipatharian corals; by comparison there have been few studies that have investigated the no less enigmatic, but possibly just as important infauna. To help fill this knowledge gap, the macrofaunal community was sampled from a total of five stations along a northerly transect (capturing water depths from $\sim 130 \mathrm{~m}$ to $\sim 3300 \mathrm{~m}$ ), on Senghor Seamount (NE Atlantic). The focus of this study is on the polychaete communities. Polychaete abundance peaked at the summit and a mid-slope station $(\sim 1500 \mathrm{~m})$, a pattern mirrored by the biomass values. The polychaete community along the transect appeared to be particularly diverse, with 135 species nominally identified to putative species from a total of 954 individuals. A diversity maximum was identified on the upper slope at $\sim 800 \mathrm{~m}$ depth, with species diversity, richness and evenness also all peaking at this station. Depth is likely to be a significant factor in determining levels of similarity between stations.
\end{abstract}

\section{Introduction}

Seamounts are defined as topographic features that rise $>1000 \mathrm{~m}$ above the surrounding seafloor; inactive volcanoes which punctuate the often more featureless abyssal plain. It is estimated that at least 33000 seamounts exist globally and constitute $\sim 5 \%$ of the global ocean floor $(\sim 17$ million $\mathrm{km}^{2}$ ) (Yesson et al., 2011). The high global abun- dance of seamount ecosystems still represents an immense challenge to scientists, thus it is somewhat unsurprising that $<0.3 \%$ have been sampled biologically in any detail, despite significant interest in these features (Ramirez-Llodra et al., 2010). Seamounts are often typified by highly rich and diverse communities of predominantly large suspension feeding organisms such as gorgonians and antipatharian corals, which are often the focus of seamount research (Bartsch, 2008; McClain et al., 2009; Clark et al., 2010; McClain, 2010; Rowden et al., 2010; Simpson and Watling, 2010; Bo et al., 2011; Sautya et al., 2011; Tracey et al., 2011). Many studies have also concentrated upon seamount fish populations (Clark, 1999; Matthiesson et al., 2002; Diekmann, 2006; Christiansen et al., 2009a; Menezes et al., 2009; Morato et al., 2009; Hirch and Christiansen, 2010) with relatively few focussed upon the infauna (Gillet and Dauvin, 2000, 2003; Richer De Forges et al., 2000; Koslow et al., 2001; Surugiu et al., 2008).

Deep-sea macrofauna communities are known to be strongly influenced by bathymetric gradients; these shape community assemblage structure, diversity and standing stock (Hessler and Sanders, 1967; Grassle et al., 1979; Rex, 1981; Flach and de Bruin, 1999; Narayanaswamy et al., 2005; 2010a, b; 2013). Depth stratification of benthic communities can reflect environmental gradients of temperature, dissolved oxygen concentration and food availability (Clark et al., 2010); these gradients alter faunal composition to such a considerable degree that more faunal change may be witnessed over $1000 \mathrm{~m}$ vertically than $1000 \mathrm{~km}$ horizontally (Grassle and Maciolek, 1992; Longhurst, 1998; Clark et al., 2010). Consequently depth is thought to be the dominant controlling factor of seamount benthic community composition (Koslow et al., 2001; Schalcher-Hoenlinger et al., 


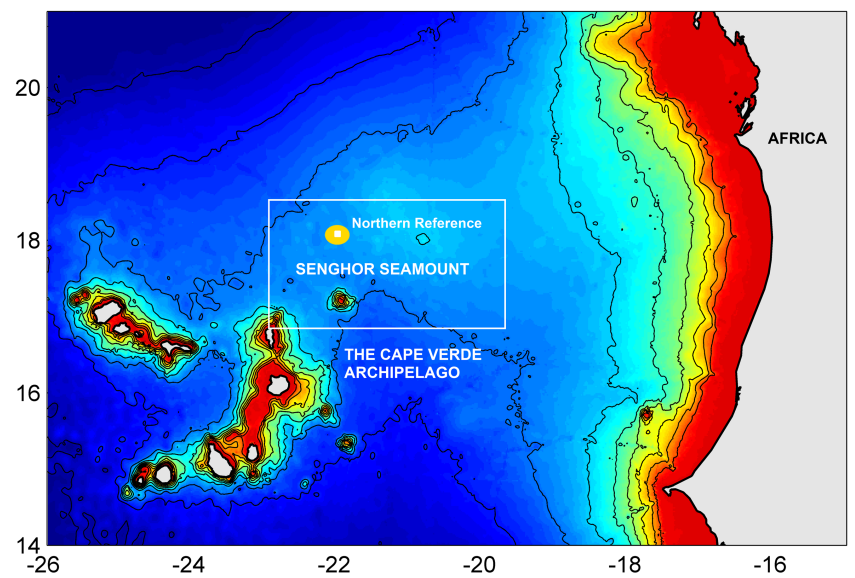

Fig. 1a. Senghor Seamount, located in the Cape Verde Archipelago, $60 \mathrm{~nm}$ northeast of the island of Sal and $\sim 550 \mathrm{~km}$ from the African mainland. Northern reference station also displayed. Data extracted from Smith and Sandwell (1997) dataset, created by A. Dale (SAMS).

2005; Clark et al., 2010; Rex and Etter, 2010). Whilst the megafauna assemblage structure and abundance variation with depth has been investigated on individual seamounts (McClain, 2010), changes in the macrofauna community in relation to a bathymetric gradient on individual seamounts remains relatively unexplored.

Polychaetes are frequently found to dominate deep-sea environments (Gage and Tyler, 1991; Gage, 2004; Surugiu et al., 2008) including seamount macrofauna communities (Gillet and Dauvin, 2000; 2003; Surugiu et al., 2008). Surugiu et al. (2008) reported that polychaetes represented up to $70 \%$ of the benthic macrofauna communities of some of the NE Atlantic seamounts (e.g. Irving, Plato and Meteor seamounts); the dominance of deep-sea communities by polychaetes enables this taxon to be used as an indicator of overall changes in population and community structure of deep-sea environments.

The aim of this study was to investigate the macro-infauna polychaetes on Senghor Seamount. More specifically, we aimed to determine if there were any changes in standing stock, diversity and composition across a northern transect, starting at the summit, capturing the slope and base environments, and ending at a reference station on the neighbouring plain which was not thought to be directly influenced by any intermediate-scale topography.

\section{Materials and methods}

\subsection{Sampling region}

This current study focussed on Senghor Seamount, a relatively isolated topographical feature located in the Cape Verde Archipelago $\sim 60$ nautical miles $(\mathrm{nm})$ northeast of

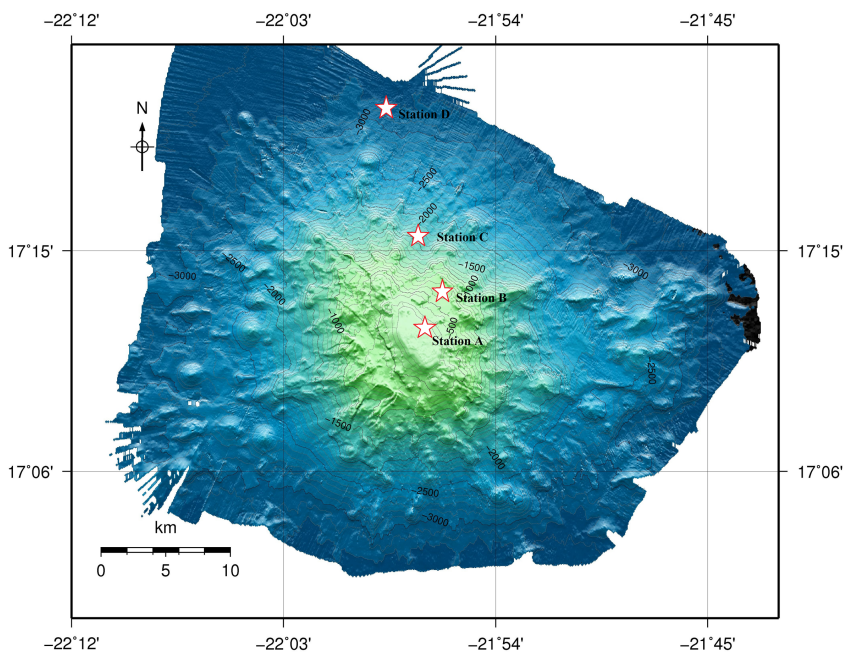

Fig. 1b. Senghor Seamount with the locations of the four stations on the northern transect minus the reference station (summit plateau depth $\sim 130 \mathrm{~m}$, base depth $\sim 3200-3300 \mathrm{~m}$ ). Adapted by A. Chivers, original data and map created by Thor Hansteen and Alexander Schmidt, GEOMAR.

the island of Sal $\left(17.17^{\circ} \mathrm{N}, 21.92^{\circ} \mathrm{W}\right)$ (Fig. 1a). Senghor Seamount is fairly circular and symmetrical in shape, with a summit plateau at just $\sim 130 \mathrm{~m}$ water depth and a northern base located at a depth of $\sim 3200-3300 \mathrm{~m}$ (Fig. 1b). It is situated in a meso- to oligotrophic region of the ocean and thus the food supply to the seafloor is expected to be somewhat reduced; an oxygen minimum zone (OMZ) is also present, with the lowest values previously detected in the region of $\sim 400 \mathrm{~m}$ water depth (Christiansen et al., 2009b).

Data presented in this study were derived from samples that were collected from a northerly transect during cruise M79/3 of R/V Meteor in October 2009. Additional transects were sampled across east, west and south aspects; however sampling difficulties prevented the achievement of our full sampling aims. Only data from the northern transect is therefore presented here; this may restrict our ability to fully describe infaunal diversity and to detect expected differences with depth at Senghor Seamount.

\subsection{Sampling methods}

A total of five stations were sampled; four stations on the seamount itself at depths ranging from $\sim 130$ to $\sim 3200 \mathrm{~m}$, and a reference station situated $60 \mathrm{~nm}$ to the north (depth $\sim 3300 \mathrm{~m}$ ) (Table 1 and Fig. 1b). The macrofauna were sampled using the German Multicorer (MUC), which has a core diameter of $94 \mathrm{~mm}$, equivalent to $69.4 \mathrm{~cm}^{2}$ surface area per core. Three deployments were made at each station, with a minimum of three cores taken from each deployment (i.e. a total of nine cores per station) (Table 1). The upper $5 \mathrm{~cm}$ of sediment was sliced for faunal analysis and each sediment sample placed into a $4 \%$ formaldehyde solution for 
Table 1. Depth and position of stations sampled on and near Senghor Seamount.

\begin{tabular}{lrrrrr}
\hline Station & $\begin{array}{r}\text { Depth } \\
(\mathrm{m})\end{array}$ & $\begin{array}{r}\text { Latitude } \\
(\mathrm{N})\end{array}$ & $\begin{array}{r}\text { Longitude } \\
(\mathrm{W})\end{array}$ & $\begin{array}{r}\text { No. of } \\
\text { replicate } \\
\text { deployments }\end{array}$ & $\begin{array}{r}\text { No. of } \\
\text { cores/ } \\
\text { deployment }\end{array}$ \\
\hline A (summit plateau) & 133 & $17^{\circ} 12.30^{\prime}$ & $21^{\circ} 57.70^{\prime}$ & 3 & 3 \\
B (upper slope) & 834 & $17^{\circ} 13.80^{\prime}$ & $21^{\circ} 57.29^{\prime}$ & 3 & 3 \\
C (mid-slope) & 1534 & $17^{\circ} 15.57^{\prime}$ & $21^{\circ} 59.97^{\prime}$ & 3 & 3 \\
D (base) & 3241 & $17^{\circ} 21.75^{\prime}$ & $21^{\circ} 57.90^{\prime}$ & 3 & 3 \\
E (reference) & 3295 & $18^{\circ} 05.00^{\prime}$ & $22^{\circ} 00.20^{\prime}$ & 3 & 3 \\
\hline
\end{tabular}

a minimum of two days, enabling the tissues to fix prior to sediment washing and thus to reduce damage to the individuals. The samples were then gently washed on a $250 \mu \mathrm{m}$ mesh sieve with filtered $(20 \mu \mathrm{m}$ mesh size) seawater, and further rinsed in freshwater before being transferred to $70 \%$ ethanol with added $2 \%$ glycol.

The macrofauna were initially sorted into major taxonomic groups and then counted. The polychaete fauna were then pooled and a wet weight biomass value obtained using a Sartorius BP61S balance. The polychaetes were then further identified to the lowest possible taxonomic level, nominally to putative species level (collectively referred to as species from here on in). Additional samples were also collected for the analysis of a number of environmental variables. Sediment characteristics (mean grain size and mud content) were obtained from MUC cores and are representative of the sediment characteristics at each depth site. Temperature, salinity and oxygen concentration values were obtained from CTD (conductivity/temperature/depth profiler) deployments at each depth range.

\subsection{Data analysis}

Polychaete abundance and biomass values per core were pooled as pseudo-replicates to form one replicate per deployment. These standing stock values were then averaged and standardised for each station to either number of individuals per $\mathrm{m}^{2}$ or grams of wet weight biomass per $\mathrm{m}^{2}$. A number of diversity indices were calculated: Margalef's richness $(d)$, Shannon's diversity $\left(H^{\prime} \operatorname{loge}\right)$, Pielou's evenness $\left(J^{\prime}\right)$ and Simpson's dominance $(1-\lambda)$, for each station using PRIMER v6 (Clarke and Warwick, 2001). The use of these diversity indices enables analysis of between station alpha diversity values, with each index varying in its sensitivity to the species richness and evenness components of a species data set; they also vary in the degree to which they are influenced by sample size. It was therefore deemed prudent to include four diversity indices within the diversity analysis. An ANOVA (analysis of variance) test was used to evaluate any significant differences between abundance, biomass and the diversity indices for each station.

Multivariate analysis was undertaken using both cluster analysis and non-metric multi-dimensional scaling (MDS)

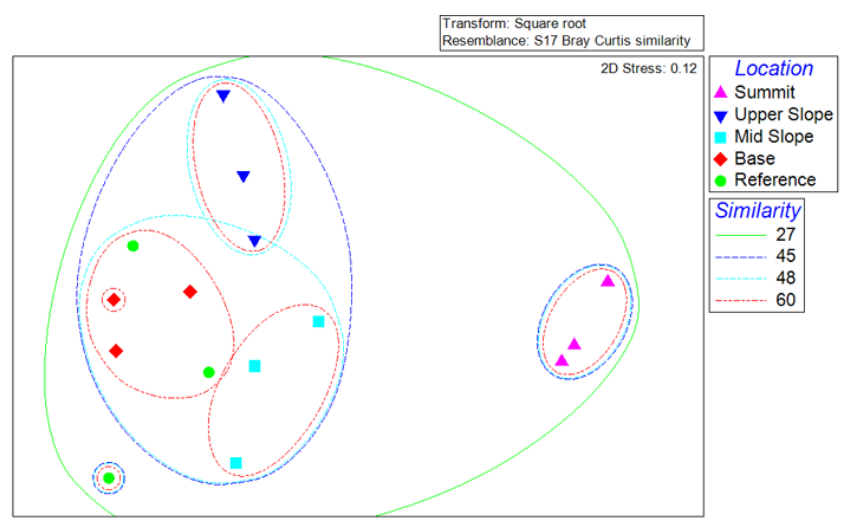

Fig. 2. Non-metric multi-dimensional scaling (MDS) ordination of the polychaete families along the northern transect on Senghor Seamount $(27,45,48$, and $60 \%$ similarity levels defined by cluster analysis).

also using the PRIMER package v6 (Clarke and Warwick, 2001), in order to investigate the similarity between depth stations in terms of both family (Fig. 2) and species community composition (Figs. 4, 5). Square root transformation of the species abundance data was undertaken and a Bray-Curtis similarity matrix generated. A similarity profile test (SIMPROF) was undertaken to determine if the differences seen in the cluster analysis were significant (SIMPROF $<0.05)$. In addition a similarity percentage test (SIMPER) was undertaken to determine the dissimilarity between stations, and which species contributed $>5 \%$ to dissimilarity between stations (Clarke and Warwick, 2001; Clarke and Gorley, 2006). A global ANOSIM (analysis of similarity) test was also conducted to determine if depth was a significant factor in separating deployments and a Pearson correlation test performed to determine which environmental parameters were correlated with depth. 
Table 2. Total abundance (ind. $\mathrm{m}^{-2}$ ) and biomass values $\left(\mathrm{g} \mathrm{m}^{-2}\right)$ per depth station (standard error values included). Environmental variables also included*: temperature $\left({ }^{\circ} \mathrm{C}\right.$ ITS-90), salinity (PSU), oxygen $\left(\mu \mathrm{mol} \mathrm{L}{ }^{-1}\right)$, sediment characteristics: mean grain size ( $\left.\mu \mathrm{m}\right)$, mud content $(\%)$, sorting, skewness, kurtosis.

\begin{tabular}{lrrrrrrrrrr}
\hline \multicolumn{1}{c}{ Environmental variables } & & \multicolumn{2}{c}{ Standing stock } \\
\hline Station & $\begin{array}{r}\text { Temperature } \\
\left({ }^{\circ} \text { CITS-90) }\right.\end{array}$ & $\begin{array}{r}\text { Salinity } \\
(\text { PSU })\end{array}$ & $\begin{array}{r}\text { Oxygen } \\
\left(\mu \mathrm{mol} \mathrm{L}^{-1}\right)\end{array}$ & $\begin{array}{r}\text { Mean } \\
\text { grain } \\
\text { size }(\mu \mathrm{m})\end{array}$ & $\begin{array}{r}\text { Mud } \\
\text { content } \\
(\%)\end{array}$ & $\begin{array}{r}\text { Sorting } \\
(\mu \mathrm{m})\end{array}$ & $\begin{array}{r}\text { Skewness } \\
\text { Kurtosis } \\
(\mu \mathrm{m})\end{array}$ & $\begin{array}{r}\text { Abundance } \\
\left(\mathrm{ind}_{\mathrm{m}} \mathrm{m}^{-2}\right)\end{array}$ & $\begin{array}{r}\text { Biomass } \\
\left(\mathrm{g} \mathrm{m}^{-2}\right)\end{array}$ \\
\hline Summit & 14.07 & 35.619 & 75.71 & 619.3 & 6.8 & 476.2 & 0.736 & 2.589 & $10160( \pm 1943)$ & $2.97( \pm 0.63)$ \\
Upper slope & 6.94 & 34.92 & 112.38 & - & - & - & - & - & $1136( \pm 232)$ & $0.48( \pm 0.14)$ \\
Mid-slope & 4.22 & 34.982 & 228.82 & 269.3 & 32.16 & 271.92 & 1.360 & 4.551 & $1744( \pm 251)$ & $1.22( \pm 0.30)$ \\
Base & - & - & - & 165.5 & 58.06 & 235.83 & 1.595 & 4.593 & $1264( \pm 122)$ & $0.25( \pm 0.05)$ \\
Reference & 2.58 & 34.90 & 247.35 & 168.5 & 53.15 & 225.45 & 1.442 & 4.176 & $960( \pm 269)$ & $0.33( \pm 0.12)$ \\
\hline
\end{tabular}

* Environmental values taken from CTD deployments located in the closest vicinity to multiple corer deployments. Sediment grain size and mud content values taken from the same deployment drops as polychaete fauna.

\section{Results}

\subsection{Environmental parameters}

Our results indicated that there were clear differences between each station in terms of the environmental parameters. The summit (Station A) was characterised by coarse sand, with a mean grain size of $>600 \mu \mathrm{m}$ and the lowest mud content of all the stations sampled ( $7 \%$ ) (Table 2). At the mid-slope station (Station C) fine sand tended to predominate with a higher mud content $(\sim 30 \%)$ compared to Station A (Table 2). The two deepest stations (on and off seamount) had very similar sediment characteristics with high mud content values and poorly sorted coarse silt (Table 2).

Our data support the presence of an OMZ, with the lowest $\mathrm{O}_{2}$ value detected on the summit plateau $\left(\sim 75 \mu \mathrm{mol} \mathrm{L}{ }^{-1}\right)$ and an increase at Station B (Table 2). Lowest oxygen saturation values are therefore likely to occur at an intermediate depth between these two stations. At the mid-slope Station $\mathrm{C}, \mathrm{O}_{2}$ values were more than double $\left(\sim 230 \mu \mathrm{mol} \mathrm{L}^{-1}\right)$ compared to Station B, and increased further at the reference station, Station E (Table 2). Salinity values were similar across all stations, with the highest value at the summit station and the lowest at the reference site (Table 2). Temperature declined with increasing depth from $\sim 14^{\circ} \mathrm{C}$ to a low of $\sim 2.5^{\circ} \mathrm{C}$ at the reference station (Table 2). A correlation between depth and the suite of environmental variables was undertaken and this revealed strong correlations between all variables and depth (temperature $r=-0.86$, salinity $r=-0.68$, oxygen $r=0.98$, mean grain size $r=-0.95$, mud content $r=0.99$, sorting $r=-0.92$, skewness $r=0.92$ and kurtosis $r=0.78$ ).

\subsection{Standing stock}

On the summit plateau (Station A), the number of polychaete individuals was high, with $>10000$ ind. $\mathrm{m}^{-2}$ and was followed by a noticeable decline on the upper slope (Station B: $\sim 1150$ ind. $\mathrm{m}^{-2}$ ) (Table 2). The total number of individu- als increased slightly at the mid-slope station, (Station C: $\sim 1750$ ind. $\mathrm{m}^{-2}$ ) before declining again at the base of the seamount (Station D: $\sim 1250$ ind. $\mathrm{m}^{-2}$ ) and at the reference station (Station E: $\sim 960$ ind. $\mathrm{m}^{-2}$ ). Polychaete biomass values showed a pattern very similar to that of the abundance values (Table 2), with a primary maximum at the summit (Station A) and a secondary maximum at the mid-slope (Station C). The ANOVA test revealed a significant difference between Station A abundance values and all other stations $(p<0.01)$, this was also reflected in the biomass values. No significant differences were observed between the standing stock values of the other stations.

\subsection{Polychaete family analysis}

In total 34 polychaete families were identified from the 954 polychaete individuals collected. The dominant families (in terms of total individuals) were the Syllidae (34\%), Spionidae (10\%), Cirratulidae (13\%), Chrysopetalidae (7\%) and Sabellidae (5\%) (Table 3). In terms of total number of species per family, the Syllidae dominated with 19 species in total, followed by the Spionidae (16), Cirratulidae (11), Paraonidae (9) and the Capitellidae (7). Several families were present at all stations, including the Cirratulidae, Paraonidae, Spionidae and the Syllidae, whilst the Arabellidae, Serpulidae, Nephytidae and Ampharetidae were only observed at depths $>1500 \mathrm{~m}$ (Table 3). The Dorvilleidae, Eunicidae and Lacydoniidae were only found at the summit station. A nonmetric MDS plot (Fig. 2) (all cores grouped per deployment) showed that at family level, all stations were broadly grouped with a similarity of $27 \%$. The upper-slope $(834 \mathrm{~m})$ and deeper stations had a $45 \%$ similarity in terms of family composition, whilst the base $(\sim 3200 \mathrm{~m})$ and reference station $(\sim 3300 \mathrm{~m})$ were $60 \%$ similar.

\subsection{Polychaete species diversity}

The 954 polychaete individuals collected were nominally separated into 135 species. Changes in polychaete species 


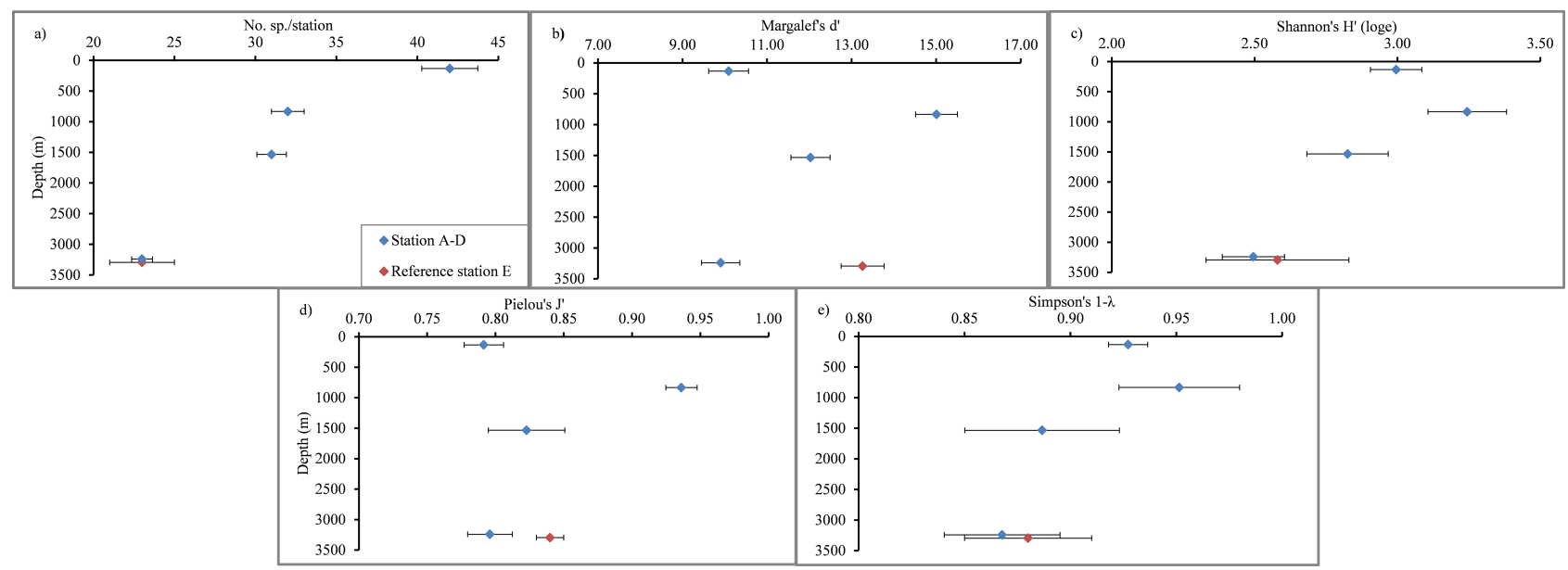

Fig. 3. Diversity of the macrobenthic polychaetes along the north transect; (a) number of species/station, (b) Margalef's richness $\left(d^{\prime}\right)$, (c) Shannon's diversity $\left(H^{\prime}\right.$ loge $)$, (d) Pielou's evenness $\left(J^{\prime}\right)$, (e) Simpson's dominance $(1-\lambda)$.

diversity along the transect are illustrated in Fig. 3. Species diversity, richness and evenness were highest on the upper slope at Station B, whereas evenness and richness were lowest at both the summit Station A and the base station on the seamount. Shannon-Wiener diversity was noticeably lower at the base station. The reference station had a higher richness value than the base station, but not diversity or dominance and only a slightly higher evenness value. The ANOVA test revealed no significant differences between any of the stations for evenness and dominance. Station A was significantly different $(p<0.01)$ to all other stations in terms of Shannon-Wiener's diversity and significantly different to Station $\mathrm{C}$ at a lower level $(p<0.05)$. This observation also held true for richness whereby the summit station was significantly different from all other stations $(p<0.01)$. There were no significant differences between all other stations in terms of the measured diversity indices.

\subsection{Multivariate analysis}

The group-average linked cluster analysis and the SIMPROF permutation test showed a remarkably low level of similarity between stations at the species level (Fig. 4), the summit station (Station A) showed no similarity to any other station $(p<0.005)$. The remaining four stations also showed relatively little similarity to one another (7\% similarity). The mid-slope, base and reference stations (Stations C, D and E) displayed a similarity level of $<10 \%$, with the seamount base Station $D$ and the reference Station E showing the greatest similarity at $26 \%(p<0.005)$. It is worth noting that the similarity of $26 \%$ is still low and it seems that, despite very similar depths, the base and reference stations differ in terms of polychaete species composition. There was no statistical evidence for any other sub-structure within each group (samples connected by dotted lines).
The non-metric MDS plot (species level, all cores grouped per deployment) (Fig. 5) also showed similar groupings of deployments and stations compared with the cluster analysis whereby the three deployments for each station formed one group. The three deployments for the summit plateau (Station A) formed one group at a similarity level of $62 \%$, quite distinct from the other four stations. In addition, the base and reference stations (Stations D and E) were quite similar in their sub-grouping (Station D deployment similarity $51 \%$, Station E deployment similarity $32 \%$ ). Using the global ANOSIM test, depth was found to be a significant factor driving deployment clustering at this seamount $(r=0.75$, $p<0.001)$. However, it appears that despite very similar depths, the base and reference stations still form two distinct clusters in terms of their polychaete species composition.

Using SIMPER, the dissimilarity between stations based on the contribution of different species was calculated (Table 4). Dissimilarity between the summit plateau (Station A) and other stations was particularly high $(>99 \%)$ and was the result, predominantly, of a single syllid species (sp. 909) which contributed $>7.5 \%$ to the total dissimilarity. Whilst sp. 977 of the family Spionidae contributed $12.6 \%$ to the dissimilarity between Station B and C, it was also found to be important in contributing to the differences between Station $\mathrm{C}$ and $\mathrm{D}$ and between Station $\mathrm{C}$ and $\mathrm{E}$.

The absence of sediment characteristic data from the upper slope (Station B, $\sim 800 \mathrm{~m}$ ) and CTD data from the base of the seamount (Station D, $\sim 3300 \mathrm{~m}$ ) resulted in depth being the only measured variable for each station. It is therefore not possible to undertake an ANOSIM test to determine which environmental variable was driving observed standing stock/diversity trends at Senghor Seamount, only depth could be tested in this way. 
Table 3. Polychaete family analysis (total no. of species, total no. of individuals, presence (Y)/absence (-), according to depth).

\begin{tabular}{|c|c|c|c|c|c|c|c|}
\hline Polychaete family & $\begin{array}{l}\text { Total no. } \\
\text { of sp. }\end{array}$ & $\begin{array}{l}\text { Total no. } \\
\text { of ind. }\end{array}$ & $\begin{array}{c}133 \mathrm{~m} \\
\text { Stat. A }\end{array}$ & $\begin{array}{r}834 \mathrm{~m} \\
\text { Stat. B }\end{array}$ & $\begin{array}{r}1534 \mathrm{~m} \\
\text { Stat. C }\end{array}$ & $\begin{array}{c}3241 \mathrm{~m} \\
\text { Stat. D }\end{array}$ & $\begin{array}{c}3295 \mathrm{~m} \\
\text { Stat. E }\end{array}$ \\
\hline Acrocirridae & 5 & 24 & $\mathrm{Y}$ & $\mathrm{Y}$ & $\mathrm{Y}$ & $\mathrm{Y}$ & Y \\
\hline Ampharetidae & 2 & 9 & - & - & $\mathrm{Y}$ & - & - \\
\hline Amphinomidae & 3 & 6 & $\mathrm{Y}$ & $\mathrm{Y}$ & $\mathrm{Y}$ & - & $\mathrm{Y}$ \\
\hline Apistobranchidae & 3 & 7 & - & $\mathrm{Y}$ & - & - & - \\
\hline Arabellidae & 1 & 1 & - & - & - & $\mathrm{Y}$ & - \\
\hline Capitellidae & 7 & 24 & $\mathrm{Y}$ & $\mathrm{Y}$ & $\mathrm{Y}$ & - & - \\
\hline Chrysopetalidae & 3 & 62 & $\mathrm{Y}$ & $\mathrm{Y}$ & $\mathrm{Y}$ & $\mathrm{Y}$ & - \\
\hline Cirratulidae & 11 & 123 & $\mathrm{Y}$ & $\mathrm{Y}$ & $\mathrm{Y}$ & $\mathrm{Y}$ & $\mathrm{Y}$ \\
\hline Dorvilleidae & 2 & 6 & $\mathrm{Y}$ & - & - & - & - \\
\hline Eunicidae & 1 & 30 & $\mathrm{Y}$ & - & - & - & - \\
\hline Flabelligeridae & 2 & 3 & $\mathrm{Y}$ & - & - & - & $\mathrm{Y}$ \\
\hline Fauveliopsidae & 1 & 9 & - & $\mathrm{Y}$ & - & - & - \\
\hline Glyceridae & 1 & 1 & - & - & - & $\mathrm{Y}$ & - \\
\hline Hesionidae & 5 & 40 & $\mathrm{Y}$ & - & $\mathrm{Y}$ & - & $\mathrm{Y}$ \\
\hline Lacydoniidae & 2 & 2 & $\mathrm{Y}$ & - & - & - & - \\
\hline Lumbrineridae & 1 & 3 & $\mathrm{Y}$ & - & $\mathrm{Y}$ & - & - \\
\hline Magelonidae & 1 & 1 & - & - & - & $\mathrm{Y}$ & - \\
\hline Maldanidae & 6 & 12 & $\mathrm{Y}$ & - & $\mathrm{Y}$ & - & $\mathrm{Y}$ \\
\hline Nephtyidae & 1 & 1 & - & - & $\mathrm{Y}$ & - & - \\
\hline Nereididae & 3 & 11 & Y & $\mathrm{Y}$ & $\mathrm{Y}$ & $\mathrm{Y}$ & $\mathrm{Y}$ \\
\hline Onuphidae & 2 & 9 & $\mathrm{Y}$ & - & - & - & $\mathrm{Y}$ \\
\hline Opheliidae & 4 & 17 & - & $\mathrm{Y}$ & $\mathrm{Y}$ & $\mathrm{Y}$ & $\mathrm{Y}$ \\
\hline Paraonidae & 9 & 37 & $\mathrm{Y}$ & $\mathrm{Y}$ & $\mathrm{Y}$ & $\mathrm{Y}$ & $\mathrm{Y}$ \\
\hline Pholoidae & 4 & 6 & $\mathrm{Y}$ & $\mathrm{Y}$ & - & - & - \\
\hline Phyllodocidae & 1 & 1 & - & - & - & - & $\mathrm{Y}$ \\
\hline Pilargidae & 2 & 2 & - & $\mathrm{Y}$ & - & - & $\mathrm{Y}$ \\
\hline Poecilochaetidae & 1 & 1 & - & - & $\mathrm{Y}$ & - & - \\
\hline Sabellidae & 3 & 47 & $\mathrm{Y}$ & - & - & $\mathrm{Y}$ & $\mathrm{Y}$ \\
\hline Serpulidae & 3 & 3 & - & - & - & $\mathrm{Y}$ & $\mathrm{Y}$ \\
\hline Sigalionidae & 5 & 7 & - & $\mathrm{Y}$ & - & $\mathrm{Y}$ & $\mathrm{Y}$ \\
\hline Sphaerodoridae & 1 & 2 & - & - & $\mathrm{Y}$ & - & - \\
\hline Spionidae & 16 & 97 & $\mathrm{Y}$ & $\mathrm{Y}$ & $\mathrm{Y}$ & $\mathrm{Y}$ & $\mathrm{Y}$ \\
\hline Syllidae & 19 & 324 & $\mathrm{Y}$ & $\mathrm{Y}$ & $\mathrm{Y}$ & $\mathrm{Y}$ & $\mathrm{Y}$ \\
\hline Terebellidae & 3 & 23 & $\mathrm{Y}$ & $\mathrm{Y}$ & $\mathrm{Y}$ & - & $\mathrm{Y}$ \\
\hline
\end{tabular}

\section{Discussion}

\subsection{Changes in polychaete standing stock with depth}

In many deep-sea environments, macrofaunal abundance is observed to decrease exponentially or linearly with depth (Etter and Rex, 1990; Cosson-Sarradin et al., 1998), however on the northern transect at Senghor Seamount, this does not appear to hold true. High polychaete abundance, which corresponds with high biomass levels, were observed on the summit of Senghor Seamount, Station A $\left(\sim 10,000\right.$ ind. $\left.\mathrm{m}^{-2}\right)$ (Table 2). This was not unexpected as the summit of the seamount at $\sim 130 \mathrm{~m}$ water depth lies at the bottom of the surface ocean layer from where organic carbon is exported into deeper waters. Comparison of macrofaunal standing stock values with total organic material was not possible due to a lack of data, however, mud content (\%) was used as a proxy for organic material availability within the sediment, as total organic material and sediment mud content are often positively correlated (Lohse et al., 1995; Janssen et al., 2005; McBreen et al., 2008; Serpetti et al., 2012). Mud content was positively correlated with depth at Senghor (Table 2), suggesting an increased availability of organic material with increasing depth. Standing stock was highest at Station A, which implies that organic material availability was not driving abundance and biomass at this station, but other variables such as temperature or current velocity may be a significant factor influencing the community at this depth (Table 2). It is known that high current velocities can re-suspend deepsea sediments, stimulating bacterial growth and influencing immigration rates to an area (Thistle et al., 1985), this may have also contributed to the high abundance observed at the summit station. 
Table 4. Cluster dissimilarity percentages as identified by similarity percentages (SIMPER). The number of species contributing to total dissimilarity between stations. Species contributing to $>5 \%$ dissimilarity included.

\begin{tabular}{|c|c|c|c|c|c|}
\hline \multirow[t]{2}{*}{ Stations } & \multirow{2}{*}{$\begin{array}{r}\text { Dissimilarity } \\
\%\end{array}$} & \multirow{2}{*}{$\begin{array}{r}\text { No. sp. } \\
\text { contributing } \\
\text { dissimilarity }\end{array}$} & \multicolumn{3}{|c|}{ Sp. contributing to $>5 \%$ dissimilarity } \\
\hline & & & Family & Species & $\begin{array}{r}\text { Contribution } \\
\%\end{array}$ \\
\hline \multirow{4}{*}{ A-B } & \multirow{4}{*}{$99.5 \%$} & \multirow{4}{*}{42} & Syllidae & sp. 909 & 8.3 \\
\hline & & & Cirratulidae & sp. 997 & 6.2 \\
\hline & & & Chrysopetalidae & sp. 900 & 6.0 \\
\hline & & & Syllidae & sp. 907 & 5.6 \\
\hline \multirow{4}{*}{$\mathrm{A}-\mathrm{C}$} & \multirow{4}{*}{$99.5 \%$} & \multirow{4}{*}{44} & Syllidae & sp. 909 & 7.6 \\
\hline & & & Cirratulidae & sp. 997 & 5.7 \\
\hline & & & Syllidae & sp. 907 & 5.2 \\
\hline & & & Spionidae & sp. 977 & 5.0 \\
\hline \multirow{4}{*}{$\mathrm{A}-\mathrm{D}$} & \multirow{4}{*}{$99.9 \%$} & \multirow{4}{*}{37} & Syllidae & sp. 909 & 8.0 \\
\hline & & & Cirratulidae & sp. 997 & 6.0 \\
\hline & & & Chrysopetalidae & sp. 900 & 5.7 \\
\hline & & & Syllidae & sp. 907 & 5.5 \\
\hline \multirow{4}{*}{ A-E } & \multirow{4}{*}{$100.0 \%$} & \multirow{4}{*}{41} & Syllidae & sp. 909 & 8.4 \\
\hline & & & Cirratulidae & sp. 997 & 6.2 \\
\hline & & & Chrysopetalidae & sp. 900 & 6.0 \\
\hline & & & Syllidae & sp. 907 & 5.6 \\
\hline \multirow{2}{*}{$\mathrm{B}-\mathrm{C}$} & \multirow{2}{*}{$97.2 \%$} & \multirow{2}{*}{41} & Spionidae & sp. 977 & 12.6 \\
\hline & & & Cirratulidae & sp. 1000 & 5.1 \\
\hline \multirow{3}{*}{ B-D } & \multirow{3}{*}{$97.1 \%$} & \multirow{3}{*}{37} & Paraonidae & sp. 991 & 11.8 \\
\hline & & & Cirratulidae & sp. 1002 & 10.1 \\
\hline & & & Sabellidae & sp. 968 & 6.7 \\
\hline \multirow{2}{*}{ B-E } & \multirow{2}{*}{$98.7 \%$} & \multirow{2}{*}{42} & Spionidae & sp. 970 & 8.2 \\
\hline & & & Cirratulidae & sp. 1002 & 6.2 \\
\hline \multirow{5}{*}{$\mathrm{C}-\mathrm{D}$} & \multirow{5}{*}{$91.6 \%$} & & Spionidae & sp. 977 & 10.8 \\
\hline & & & Spionidae & sp. 981 & 10.5 \\
\hline & & 34 & Cirratulidae & sp. 1002 & 8.9 \\
\hline & & & Sabellidae & sp. 968 & 5.9 \\
\hline & & & Cirratulidae & sp. 1000 & 5.0 \\
\hline & & & Spionidae & sp. 977 & 13.5 \\
\hline & & & Spionidae & sp. 970 & 6.9 \\
\hline C-E & $97.6 \%$ & 40 & Cirratulidae & sp. 1000 & 5.7 \\
\hline & & & Cirratulidae & sp. 1002 & 5.2 \\
\hline & & & Spionidae & sp. 981 & 15.1 \\
\hline & & & Spionidae & sp. 970 & 9.1 \\
\hline D-E & $82.4 \%$ & 33 & Sabellidae & sp. 968 & 7.5 \\
\hline & & & Cirratulidae & sp. 1002 & 7.1 \\
\hline
\end{tabular}

At the "upper" mid-slope station (Station B $800 \mathrm{~m}$ ) the presence of the oxygen minimum zone may have had an influence upon standing stock. Levin et al., (2000) noted that standing stock increased in the lower boundary zone below an OMZ centre in the Arabian Sea, and that was related to the increased organic material at these depths. Station B has a considerably lower standing stock compared to stations sampled shallower and deeper, yet is located be- low the OMZ centre. As there was not a station sampled from within the centre of the $\mathrm{OMZ}(\sim 400 \mathrm{~m})$ we are unable to say whether this "low" value for Station B is the minimum value found for stations along this northern transect. A lack of quantitative macrofaunal studies of NE Atlantic seamounts prevents any direct comparisons to this study. However, three sites at depths comparable to our study, with different productivity regimes, were sampled as part of 


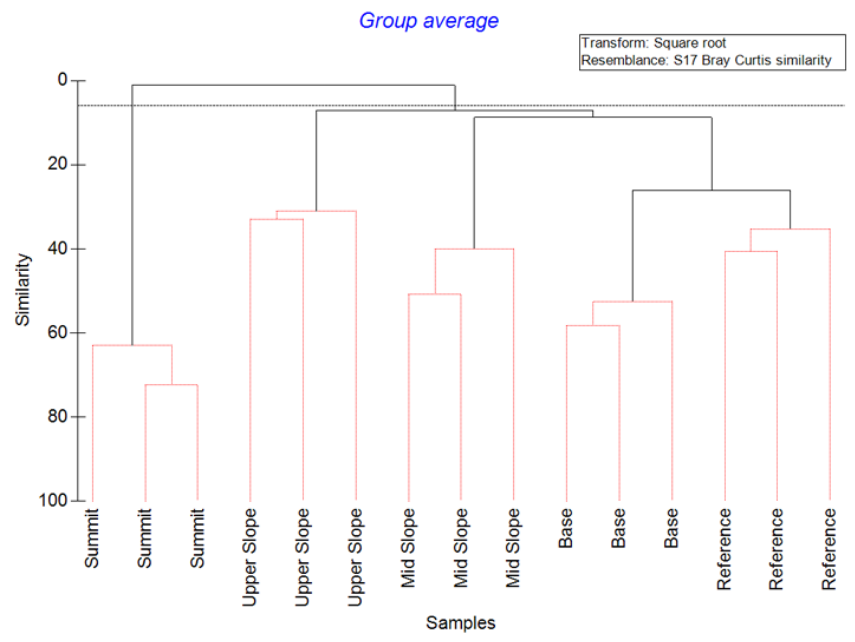

Fig. 4. Hierarchical, group-average linkage Cluster analysis on deployment replicate resemblance for polychaete species along the northern transect of Senghor Seamount. The similarity profile (SIMPROF) test $(p<0.05)$ defines non-random clusters in the analysis.

the EUMELI-JGOFS (EUtrophic, MEsotrophic and oLIgotrophic sites-Joint Global Ocean Flux Study) benthic program on the Cape Verde Rise (Galeron, et al., 2000). Polychaete abundance at the eutrophic site was almost double that found at a comparable depth on Senghor Seamount (Station $\mathrm{C} \sim 1500 \mathrm{~m}$ ) and the mesotrophic site had similar abundance values compared to the deep stations sampled in this study $(\sim 3200 \mathrm{~m})$. Abundance values at Senghor are also roughly comparable to sites sampled during the BIOZAIRE 2 project where deep-sea canyon systems were investigated in the southeast Atlantic (Galeron et al., 2009).

\subsection{Changes in polychaete family diversity}

At Senghor Seamount a total of 34 polychaete families were identified from 954 individuals. When comparing our results with those of Gillet and Dauvin 2000, 2003; and Surugiu et al., 2008, we found our values were higher than those from seamounts in the nearby Azores region whereby Atlantis Seamount had 18 families and 403 individuals, whilst Hyeres Seamount had 13 families and 346 individuals. A ratio of polychaete families/total individuals collected was compared from the different seamounts and clear similarities between Senghor $(34 / 954=0.036)$, Atlantis $(18 / 403=0.045)$ and Hyeres $(13 / 346=0.038)$ seamounts were observed. Five families dominated the polychaete fauna at Senghor, contributing $>95 \%$ of the total polychaete abundance (see Table 3). Surugiu et al., (2008) also identified a number of dominant polychaete families, e.g. the Onuphidae $(\sim 28 \%$, 1053 ind.), Syllidae ( $18 \%, 699$ ind.), Eunicidae ( $\sim 16 \%$, 600 ind.), and the Amphinomidae ( 12\%, 439 ind.); in total

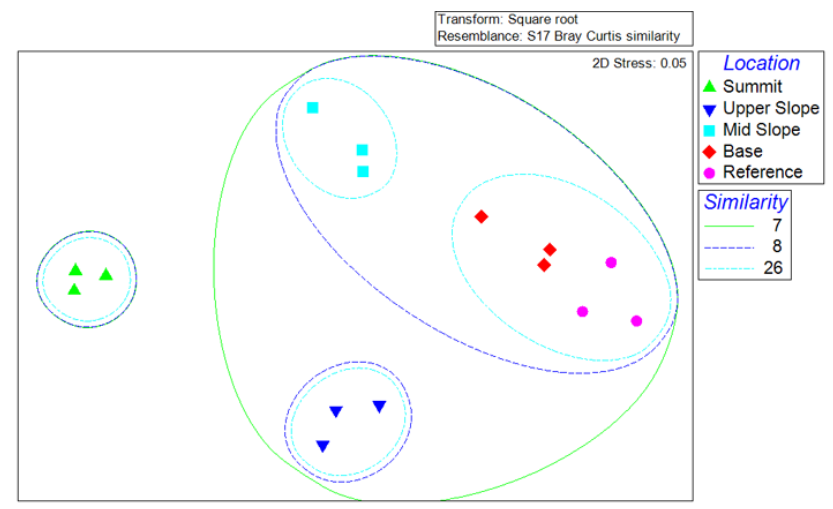

Fig. 5. Non-metric multi-dimensional scaling (MDS) ordination of the polychaete species along the northern transect on Senghor Seamount $(7,8$, and $26 \%$ similarity levels defined by cluster analysis).

10 families were identified which represented $>90 \%$ of the total fauna collected.

Few similarities were observed between Senghor Seamount and the Azores seamounts. Many more families were identified at Senghor Seamount, although this may be the result of the higher number of individuals collected, it may also be a result of different sampling gear and mesh size used in this study. It is difficult to draw direct comparisons with the seamounts sampled by Gillet and Dauvin, 2000, 2003; and Surugiu et al., 2008, as a variety of qualitative sampling gear was used, e.g. epibenthic dredges and beam trawls (with a mesh size of $2-5 \mathrm{~mm}$ ), which in turn sampled the hard substrate, e.g. stones, corals. Dominant families were also very different, the only similarity being the Syllidae family which dominated on Josephine and Meteor seamounts (Gillet and Dauvin, 2000, 2003). On Senghor Seamount there does not appear to be such a distinct bathymetric zonation of families, with a relatively high degree of similarity between stations in terms of family similarity (Fig. 2).

\subsection{Changes in polychaete species diversity and composition}

At the summit and deeper stations on Senghor Seamount, species richness and evenness were both relatively low, with a peak observed at the upper-slope station $(\sim 800 \mathrm{~m}$ depth). This peak in diversity was found at a shallower depth compared to many other deep-sea polychaete studies where the observed diversity maxima occurred at 1400-1800 m along the Hebridean Slope (Paterson and Lambshead, 1995), whereas in the tropical NE Atlantic, Cosson-Sarradin et al. (1998) found polychaete diversity peaked at $\sim 2000 \mathrm{~m}$. In the Faroe-Shetland Channel polychaete species- and genuslevel diversity occurred at depths between 450-550 m (Bett, 2001; Narayanaswamy et al., 2005, 2010a, b). By removing 
the summit station (Station A) from our analysis a different diversity versus depth pattern is observed; polychaete diversity appears to show a gradual and almost linear decrease in diversity with increasing depth across the remaining seamount stations. The results of the ANOVA test revealed no significant differences between all stations in terms of dominance and evenness but species diversity was significantly different at the summit compared to the other stations (Station B, D and E; $p<0.01$ ) and to Station $\mathrm{C}$ at a lower level $(<0.05)$.

As already highlighted the environmental conditions at the summit station are very different to the others on Senghor Seamount. The summit may experience increased current velocities which may explain the poorly sorted coarse sand sediment with low particle size diversity (Table 2) as well as having a low oxygen concentration. Particle size diversity is known to strongly correlate with faunal diversity (Etter and Grassle, 1992) and this, combined with reduced habitat heterogeneity may be some of the dominant factors reducing species diversity on the summit. It is likely that lower oxygen concentration may be driving the high evenness, diversity and richness witnessed on the upper slope (Station B), the converse of what was seen with abundance. Levin et al. (2000), observed a dramatic increase in diversity below the centre of an OMZ in the Arabian Sea, and suggested that in the lower boundary below the OMZ, diversity may increase, potentially due to low oxygen levels acting as a physical disturbance and thus limiting competitive exclusion.

There is a noticeable difference in species richness and evenness when comparing the base and reference stations (Fig. 3c). However, in terms of species composition, the base and reference stations displayed the highest between-station similarity $(>30 \%)$; however, this is still a relatively low degree of similarity, suggesting different community composition at each site, despite very similar depths. In terms of sediment characteristics, the two stations were also very similar. Unfortunately additional environmental information is not available for Station D, so it is unclear why richness and evenness may differ at these sites.

At species level the polychaete communities along the northern transect of Senghor Seamount were found to be significantly different from one another $(p<0.005)$, with the summit station (Station A) showing very low similarity $(<1 \%)$ to the remaining four stations (Figs. 4, 5). The base and reference stations (Stations D and E at $\sim 3200-3300 \mathrm{~m}$ depth) did not have a high level of similarity $(<30 \%)$ and community composition appeared to be different even though standing stock values were found to be very similar at these sites (Table 2 and Sect. 3.2). The dominant species found at the base station (sp. 981) and the reference station (sp. 970) both belonged to the same family, Spionidae; however, sp. 981 was absent from the reference station and sp. 970 was absent from the base station, thus contributing $\sim 15 \%$ to the dissimilarity between the stations. Both species were examined to determine if there were any differences in morphology and/or functional traits. Both species were found to belong not only to the same family but also the same genus (Prionospio). Under close examination a number of small morphological differences were discovered which separate the two species. Since both species are very similar we feel they probably occupy a similar ecological niche. The only discernible difference between these two stations is a slightly lower mud content at Station E (Table 2). Unfortunately CTD data was unavailable from Station D preventing us from examining other environmental variables which may explain the observed differences in community composition at the sites.

Seamounts may enable many species to co-exist over a wide bathymetric range, creating a distinct, individual and complex environment with a suite of environmental and evolutionary factors (local hydrodynamic regime, oxygen concentration and sediment characteristics) acting in concert to shape community diversity (Clark et al., 2010). Koslow et al. (2001) found that most seamount species were distributed over a wide depth range on a southern Tasmanian seamount whereas at Senghor Seamount each station appeared to have very different species compositions. However, the results here do support the theory proposed by Longhurst (1998), that more change may be witnessed over $1000 \mathrm{~m}$ vertically than $1000 \mathrm{~km}$ horizontally. In addition the findings of McClain (2010) indicate that substantial change in assemblage structure may be observed over vertical scales, often as much as a $50 \%$ change over a vertical distance of only $1500 \mathrm{~m}$, which supports our findings. Depth is a significant factor driving the clustering of deployments at Senghor Seamount (Global ANOSIM, $r=0.75, p<0.001$ ), with depth often correlated to changes in environmental conditions (Grassle et al., 1979; Clark et al., 2010). It appears that at Senghor Seamount this effect is more pronounced, with a more marked change in community composition observed between stations, in as little as a vertical distance of $700 \mathrm{~m}$.

At Senghor the explanation for observed standing stock and diversity patterns is likely to be multivariate and complex, with high temperatures, low oxygen and a coarse grain size driving differences on the summit and within the OMZ. A number of ecological theories have been proposed to explain the uni-modal patterns of species diversity observed with depth. These theories focus upon the influence of disturbance upon diversity (the intermediate disturbance hypothesis, Connell, 1978) and productivity and disturbance models, e.g. the Dynamic Equilibrium Model (DEM) (Huston, 1994). These models predict a uni-modal relationship of species diversity and depth, as observed at Senghor Seamount. The models predict low diversity at high and low productivity levels and highest diversity at intermediate productivity, with a similar prediction for disturbance (intermediate disturbance resulting in high diversity). When the effects of disturbance and productivity are combined, the situation becomes much more complex. Kondoh (2001) modified Huston's DEM model to explicitly include disturbance and 
productivity, predicting highest diversity at mid to low productivities and intermediate disturbance and lowest diversity at highly disturbed/low productivity sites or high productivity/low disturbance sites. Unfortunately the lack of environmental data for Senghor Seamount negates the possibility of testing these hypotheses for the benthic macrofauna at this seamount.

This study though based upon low sample numbers and a less than comprehensive coverage of a full bathymetric range, still adequately explores the relationship between polychaete assemblages and depth, and also a range of environmental variables on a single seamount. Due to these limitations, polychaete standing stock and diversity trends may not be fully described, but these results do suggest seamounts in the Cape Verdean region support abundant and diverse polychaete assemblages. Further investigation of this and other seamount macrobenthic assemblages in this region and worldwide will be important when seeking to gain an integrated understanding of seamount ecosystem processes.

Acknowledgements. The authors would like to thank the crew of the R/V Meteor, the chief scientist Bernd Christiansen and all scientific personnel of research cruise M79-3. We further thank Gordon Paterson for assistance with polychaete identification, Kai George and Lena Albers of the Senckenberg Institute, Wilhelmshaven, for providing additional sediment samples for the research and for hosting AC for a month long visit to the Senckenberg Institute in June 2011. Also thanks go to Natalia Serpetti for assistance with polychaete identification and statistical analysis, Rosalind Barnes for support with the sorting of sediment samples and Jirina Stehlikova for undertaking the sediment grain size analysis.

The research leading to these results has received funding from the Natural Environment Research Council (grant awarded to RT and BN) (NE/G006415/1) and the European Community's Seventh Framework Programme (FP7/2007-2013) under the HERMIONE project, grant agreement no. 226354 (awarded to BN). AC was jointly funded through a PhD studentship by the Natural Environment Research Council and from the MASTS pooling initiative (The Marine Alliance for Science and Technology for Scotland) and their support is gratefully acknowledged. MASTS is funded by the Scottish Funding Council (grant reference HR09011) and contributing institutions.

Edited by: R. Danovaro

\section{References}

Bartsch, I.: Notes on ophiuroids from the Great Meteor Seamount (Northeastern Atlantic), Spixiana, 31, 233-239, 2008.

Bett, B. J.: UK Atlantic Margin Environmental Survey: Introduction and overview of bathyal benthic ecology, Cont. Shelf Res., 21, 917-956, 2001.

Bo, M., Bertolino, M., Borghini, M., Castellano, M., Carriague, A. C., Di Camillo, C. G., Gasparini, G., Misic, C., Povero, P., Pusceddu, A., Schroeder, K., and Bavestrello, G.: Characterisitics of the mesophotic meagabenthic assemblages of the Ver- cilli Seamount (North Tyrrhenian Sea), PLoS ONE, 6, e16357, doi:10.1371/journal.pone.0016357, 2011.

Christiansen, B., Martin, B., and Hirch, S.: The benthopelagic fish fauna on the summit of Seine Seamount, NE Atlantic : Composition, population structure and diets, Deep-Sea Res. Pt. II, 56, 2705-2712, 2009a.

Christiansen, B., Brand, T., Buntzow, M., Busecke, J., Coelho, R., Correia, S., Denda, A., Diniz, T., Jung, S., Kaufmann, M., Kieneke, A., Kirriakoulakis, K., Koppelmann, R., Kuhnert, J., Kwasnitschka, T., Lamont, P., Martin, B., Montgomery, J., Peine, F., Piedade, A., Reichelt, T., Rieger, V., Schmidt, A., Stahl, H., Tiedke, J., Truscheit, T., Turnewitsch, R., Unger, K., Vogel, S., and Warneke-Cremer, C.: Structure and Function of seamount ecosystems in the Cape Verde Region, Northeast Atlantic, Cruise no. 79, Leg 3, http://www.dfg-ozean.de/fileadmin/DFG/ Berichte_METEOR/Fahrtbericht_M79-3.pdf (accessed 18th August 2011), 2009b.

Clark, M.: Fisheries for orange roughy (Hoplostethus atlanticus) on seamounts in New Zealand, Oceanol Acta, 22, 593-602, 1999.

Clarke, K. R. and Gorley, R. N.: PRIMER v5 (and v6): User manual/tutorial, PRIMER-E, Plymouth UK, p. 91 and p. 192, 2006.

Clarke, K. R. and Warwick, R. M.: Change in marine communities: An approach to statistical analysis and interpretation. 1st edition: Plymouth Marine Laboratory, Plymouth, UK, 2nd Edn., PRIMER-E, Plymouth, UK, 144 pp., 2001.

Clark, M. R., Rowden, A. A., Schlacher, T., Williams, A., Consalvey, M., Stocks, K. I., Rogers, A. D., O’Hara, T. D., White, M., Shank, T. M., and Hall-Spencer, J. M.: The ecology of seamounts: structure, function, and human impacts, Ann. Rev. Mar. Sci., 2, 253-278, 2010.

Connell, J. H.: Diveristy in tropical rain forests and coral reefs, Science, 199, 1302-1310, 1978.

Consalvey, M., Clark, M. R., Rowden, A. A., and Stocks, K. I.: Life on seamounts, in: Life in the World's Oceans, edited by: McIntyre, A., Wiley-Blackwell, UK, 123-138, 2010.

Cosson-Sarradin, N., Sibuet, M., Paterson, G. L. J., and Vangriesheim, A.: Polychaete diversity at tropical deep-sea sites, environmental effects, Mar. Ecol-Prog. Ser., 165, 173-185, 1998.

Diekmann, R., Nellen, W., and Piatkowski, U.: A multivariate analysis of larval fish and paralarval cephalopod assemblages at Great Meteor Seamount, Deep-Sea Res., 53, 1635-1657, 2006.

Etter, R. J. and Grassle, J. F.: Patterns of species diversity in the deep sea as a function of sediment particle size diversity, Nature, 360, 576-578, 1992.

Etter, R. J. and Rex, M. A.: Population differentiation decreases with depth in deep sea gastropods, Deep-Sea Res., 37, 12511261, 1990.

Flach, E. and Bruin, W. D.: Diversity patterns in macrobenthic comunities across a bathymetric range at a continental slope in the NE Atlantic, J. Sea Res., 42, 303-323, 1999.

Gage, J. D.: Diversity in deep-sea benthic macrofauna: the importance of local ecology, the larger scale, history and the Antarctic, Deep-Sea Res. Pt. II, 51, 1689-1708, 2004.

Gage, J. D. T. and Tyler, P. A.: Deep-sea biology: a natural history of organisms at the deep-sea floor, Cambridge University Press, Cambridge, 1991.

Galeron, J., Sibuet, M., Mahaut, M-L., and Dinet, A.: Variation in structure and biomass of the benthic communities at three contrasting sites in the tropical Northeast Atlantic, Mar. Ecol-Prog. 
Ser., 197, 121-137, 2000.

Galeron, J., Menot, L., Renaud, N., Crassous, P., Khripounoff, A., Treignier, C., and Sibuet, M.: Spatial and temporal patterns of benthic macrofaunal communites on the deep continental margin in the Gulf of Guinea, Deep-Sea Res. Pt. II, 56, 2299-2312, 2009.

Gillet, P. and Dauvin, J. C.: Polychaetes from the Atlantic Seamounts of the Southern Azores: biogeographical distribution and reproductive patterns, J. Mar. Biol. Assoc. UK, 80, 10191029,2000

Gillet, P. and Dauvin, J. C.: Polychaetes from the Irving, Meteor and Plato Seamounts, North Atlantic Ocean: origin and geographical relationships, J. Mar. Biol. Assoc. UK, 83, 49-53, 2003.

Grassle, J. F. and Maciolek, N. J.: Deep-sea species richness regional and local diversity estimates from quantitative bottom samples, The American Naturalist, 139, 313-341, 1992.

Grassle, J. F., Sanders, H. L., and Smith, W.: Faunal changes with depth in the deep-sea benthos, Ambio Special Report, 47-50, 1979.

Hessler, R. R. and Sanders, H. L.: Faunal diversity in the deep sea, Deep-Sea Res., 14, 65-78, 1967.

Hirch, S. and Christiansen, B.: The trophic blockage hypothesis is not supported by the diets of fishes on Seine Seamount, Mar. Ecol., 31, 1-14, 2010.

Huston, M. A.: Biological diversity-The coexistence of species on changing landscapes, Cambridge University Press, Cambridge, 1994.

Janssen, F., Huettel, M., and Witte, U.: Pore-water advection and solute fluxes in permeable marine sediment (II): benthic respiration at three sandy sites with different permeabilities (German Bight, North Sea), Limnol. Oceanogr., 50, 3, 779-792, 2005.

Kondoh, M.: Unifying the relationships of species richness to productivity and disturbance, P. R. Soc. B., 268, 269-271, 2000.

Koslow, J. A., Gowlett-Holmes, K., Lowry, J. K., O’Hara, T., Poore, G. C. B., and Williams, A.: Seamount benthic macrofauna off southern Tasmania: community structure and impacts of trawling, Mar. Ecol-Prog. Ser., 213, 111-125, 2001.

Levin, L. A., Gage, J. D., Martin, C., and Lamont, P. A.: Macrobenthic communtiy structure within and beneath the oxygen minimum zone, NW Arabian Sea, Deep-Sea Res. Pt. II, 47, 189-226, 2000

Lohse, L., Malschaert, J. F. P., Slomp, C. P., Helder, W., and vanRaaphorst, W.: Sediment-water fluxes of inorganic nitrogen compounds along the transport route of organic matter in the North Sea, Ophelia, 41, 173-197, 1995.

Longhurst, A. R.: Ecological geography of the sea,Academic Press, San Diego, CA, 389-394, 1998.

McBreen, F., Wilson, J. G., Mackie, A. S. Y., and Aonghusa, C. N.: Seabed mapping in the southern Irish Sea: predicting benthic biological communities based on sediment characteristics, Hydrobiologia, 606, 93-103, 2008.

McClain, C. R.: Assemblage structure, but not diversity change with depth on a NE Pacific seamount, Mar. Ecol., 31, 1-12, 2010.

McClain, C.R., Lundsten, L., Ream, M., Barry, J., and Devogelaere, A.: Endemicity, biogeography, composition, and community structure on a Northeast Pacific seamount, PLoS ONE, 4, e4141, doi:10.1371/journal.pone.0004141, 2009.

Menezes, G. M., Rosa, A., Melo, O., and Pinho, M. R.: Demersal fish assemblages off the Seine and Sedlo Seamounts (Northeast- ern Atlantic), Deep-Sea Res. Pt. II, 56, 2683-2704, 2009.

Morato, T., Bulman, C., and Pitcher, T. J.: Modelled effects of primary and secondary production enhancement by seamounts on local fish stocks, Deep-Sea Res. Pt. II, 56, 2713-2719, 2009.

Narayanaswamy, B. E., Bett, B. J., and Gage, J. D.: Ecology of bathyal polychaete fauna at an Arctic-Atlantic boundary (FaroeShetland Channel, Northeast Atlantic), Mar. Biol. Res., 1, 20-32, 2005.

Narayanaswamy, B. E., Bett, B. J., and Hughes, D. J.: Deepwater macrofaunal diversity in the Faroe-Shetland region (NE Atlantic): a margin subject to an unusual thermal regime, Mar. Ecol-Prog. Ser., 31, 237-246, 2010a.

Narayanaswamy, B. E., Renaud, P. E., Duineveld, G. C. A., Berge, J., Lavaleye, M. S. S., Reiss, H., and Brattegard, T.: Biodiversity trends along the Western European Margin, PloS ONE, 5, e14295, doi:10.1371/journal.pone.0014295, $2010 \mathrm{~b}$.

Narayanaswamy, B. E., Hughes, D. J., Howell, K. L., Davies, J., and Jacobs, C.: First observations of megafaunal communities inhabiting George Bligh Bank, Northeast Atlantic, Deep-sea Res. Pt. II, in press, doi:10.1016/j.dsr2.2013.03.004, 2013.

Paterson, G. L. J. and Lambshead, P. J. D.: Bathymetric patterns of polychaete diversity in the Rockall Trough, Northeast Atlantic, Deep-Sea Res. Pt. I, 42, 1199-1214, 1995.

Ramirez-Llodra, E., Brandt, A., Danovaro, R., De Mol, B., Escobar, E., German, C. R., Levin, L. A., Martinez Arbizu, P., Menot, L., Buhl-Mortensen, P., Narayanaswamy, B. E., Smith, C. R., Tittensor, D. P., Tyler, P. A., Vanreusel, A., and Vecchione, M.: Deep, diverse and definitely different: unique attributes of the world's largest ecosystem, Biogeosciences, 7, 2851-2899, doi:10.5194/bg-7-2851-2010, 2010.

Rex, M. A.: Community structure in the deep-sea benthos, Annu. Rev. Ecol. Syst., 12, 331-353, 1981.

Rex, M. A. and Etter, R. J.: Deep-sea biodiversity: Pattern and scale, Harvard University Press, Havard, 354, 171-198, 2010.

Richer De Forges, B. R., Koslow, J. A., and Poore, G. C. B.: Diversity and endemism of the benthic seamount fauna in the southwest, Nature, 405, 944-947, 2000.

Rowden, A. A., Schlacher, T. A., Williams, A., Clark, M. R., Stewart, R., Althaus, F., Bowden, D. A., Consalvey, M., Robinson, W., and Dowdney, J.: A test of the seamount oasis hypothesis: seamounts support higher epibenthic megafaunal biomass than adjacent slopes, Mar. Ecol., 31, 1-12, 2010.

Sautya, S., Ingole, B., Ray, D., Stöhr, S., Samudrala, K., Raju, K. A. K., and Mudholkar, A.: Megafaunal community structure of Andaman Seamounts including the back-arc basin - A quantitative exploration from the Indian Ocean, PloS ONE, 6, e16162, doi:10.1371/journal.pone.0016162, 2011.

Serpetti, N., Heath, M., Rose, M., and Witte, U.: High resolution mapping of sediment organic matter from acoustic reflectance data, Hydrobiologia, 680, 265-284, 2012.

Simpson, A. and Watling, L.: Precious corals (Coralliidae) from Northwestern Atlantic Seamounts, J. Mar. Biol. Assoc. UK, 91, (Special issue 02), 369-82, 2010.

Smith, W. H. F. and Sandwell, D. T.: Global seafloor topography from satellite altimetry and ship depth soundings, Science, 277, 1957-1962, 1997.

Surugiu, V., Dauvin, J. C., Gillet, P., and Ruellet, T.: Can seamounts provide a good habitat for polychaete annelids?, Example of the Northeastern Atlantic Seamounts, Deep-Sea Res. Pt. I, 55, 1515- 
1531, 2008.

Thistle, D., Yingst, J. Y., and Fauchald, K.: A deep-sea benthic community exposed to strong near-bottom currents on the Scotia Rise (Western Atlantic), Mar.Geo.,66, 91-112, 1985.
Tracey, D. M., Rowden, A. A., Mackay, K. A., and Compton, T.: Habitat-forming cold-water corals show affinity for seamounts in the New Zealand region, Mar. Ecol. Prog. Ser., 430, 1-22, 2011. Yesson, C., Clark, M. R., Taylor, M. L., and Rogers, A. D.: The global distribution of seamounts based on 30 arc seconds bathymetry data, Deep-Sea Res. Pt. I, 58, 442-453, 2011. 